Intersections

Canadian Journal of Music

Revue canadienne de musique
Intersections

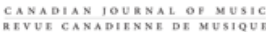

\title{
The Apostasy Of George Rochberg
}

\section{Alan Gillmor}

Volume 29, numéro 1, 2009

URI : https://id.erudit.org/iderudit/039109ar

DOI : https://doi.org/10.7202/039109ar

Aller au sommaire du numéro

\section{Éditeur(s)}

Canadian University Music Society / Société de musique des universités canadiennes

ISSN

1911-0146 (imprimé)

1918-512X (numérique)

Découvrir la revue

Citer cet article

Gillmor, A. (2009). The Apostasy Of George Rochberg. Intersections, 29(1),

32-48. https://doi.org/10.7202/039109ar

\section{Résumé de l'article}

Une exploration du rejet bien connu, chez George Rochberg, du modernisme musical — plus particulièrement du sérialisme — au début des années 1960. Cet article examine la conception que Rochberg se faisait de l'espace et du temps musical, de la durée en musique et de ses rapports avec la mémoire, l'identité, l'intuition, ainsi que la perception dans le développement de l'expérience humaine. Il explique la notion d'« écart métaphysique entre la conscience humaine et le cosmos » que Rochberg fait en partie remonter à la proposition de Wittgenstein selon laquelle le jugement éthique et esthétique résiderait en dehors des propriétés du langage. Selon Rochberg, le sérialisme ne parvient pas à fournir un modèle organique tridimensionnel de la durée qui correspondrait à celui qui provient de la perception humaine du temps : passé (mémoire) et futur (prévision) fusionnent en un présent continu, et l'équilibre décisif entre information et redondance se révèle défaillant.
Tous droits réservés (C) Canadian University Music Society / Société de musique des universités canadiennes, 2009
Ce document est protégé par la loi sur le droit d'auteur. L'utilisation des services d'Érudit (y compris la reproduction) est assujettie à sa politique d'utilisation que vous pouvez consulter en ligne.

https://apropos.erudit.org/fr/usagers/politique-dutilisation/ 


\title{
THE APOSTASY OF GEORGE ROCHBERG
}

\author{
Alan Gillmor
}

In the early 196os, George Rochberg-then one of the leading figures of the post-Schoenbergian wing of modernism in America-began moving rapidly back to the future in his search for a musical language that would free him from what he increasingly began to see as the limited expressive range of serialism. Interestingly, much of the original attraction of serialism for Rochberg was what he perceived to be its power to penetrate deeply into the realm of the unconscious, to reveal the darker side of the psyche, rather like a kind of sonic depth psychology. Now, however, he began to see the over-rationalized, systematized dissonance of the neo-Schoenbergians as emotionally restricted and one-dimensional, a kind of "musical esperanto,"1 incapable of expressing the larger dimensions of life. The result was a series of works-the most famous (or infamous perhaps) of these being the Third String Quartet (1971-2), which, by the composer's own admission, draws "heavily on the melodic-harmonic language of the nineteenth century" among the composer's peers. Clearly a collective nerve had been hit, for few American composers of Rochberg's generation have generated such a violent reaction and response, both pro and con, but mostly-at least initially-the latter. The gloves, as it were, came off as Rochberg was accused, either directly or by implication, of being a scurrilous traitor to the cause, a coward, a master forger and shameless pasticheur, a parasite, a skilful mimic, and-most luridly-a kind of cultural grave robber. ${ }^{3}$

In the fall of 1961, within days of completing his serial Second String Quartet, Rochberg revealed something of his essentially "romantic" world view in a letter to the Canadian composer Istvan Anhalt, whom he had met earlier that year at an International Conference of Composers held in Stratford, Ontario. 4

1 Rochberg, liner note for the 1973 recording of the Third String Quartet (Nonesuch H-71283); reprinted in Joan DeVee Dixon, George Rochberg: A Bio-Bibliographic Guide to His Life and Works (Stuyvesant, NY: Pendragon, 1992), 139.

2 Rochberg, ibid., 141.

3 See, for example, Steven D. Block, “George Rochberg: Progressive or Master Forger?” Perspectives of New Music 21, nos. 1-2 (Fall-Winter 1982 / Spring-Summer 1983): 407-9; Lance W. Brunner, “George Rochberg: “The Concord Quartets," Notes 38, no. 2 (December 1981): 423-6; Andrew Porter, “Musical Events: Questions," New Yorker, 12 February 1979, 109-15; and Hugh Wood, “Thoughts on a Modern Quartet," Tempo 111 (December 1974): 23-6.

4 For a discussion of Rochberg's and Anhalt's different responses to modernism, see Eagle Minds: Selected Correspondence of Istvan Anhalt and George Rochberg (1961-2005), ed. Alan M. Gillmor (Waterloo: Wilfrid Laurier University Press, 2007), xiii-xxxvii. Portions of this essay first appeared in my introduction to this volume. 
Reacting to performances of music by Milton Babbitt, Elliott Carter, and Leon Kirchner that he had heard in New York on 6 September, he wrote:

I came away from the concert feeling one overpowering dissatisfaction: namely, the inability of any of the three composers to make a passionate statement, to produce vibrant music that catches you up \& does not let go until it has said all it intends to. In short the burning intensity of a Beethoven or Mahler or the dark somber intensity of a Brahms or the bite of a Schoenberg or Varèse are not there because the engagement with life $\&$ reality which produces suffering is not there. If music is merely the writing of the "pieces" I withdraw my criticism. But that is the least of what music is. I do not care if the technical aspects of Carter's or Kirchner's music, each in its own peculiar way, are more than competent, polished, sure. Rimsky-Korsakov was a damned good craftsman; so was Dvoŕák; also Telemann \& a host of others. But they were not visionaries. Give me the awkwardness of Mussorgsky with its wild passion; or the occasionally clumsy ways of Charles Ives with its ability to overcome its own inadequacy. Music today is more than sounds and sound manipulations, at least for me. It is a way of reaching the ineffable or exorcising the Devil. It is duende, the black sounds of human blood as Garcia Lorca says. We have to dip ourselves back into life. We have to get behind the external façade of phenomena. Neither Babbitt, Carter nor Kirchner is capable of this \& consequently their music ultimately remains stylistic effort which will be washed away with the next new wave whatever it may be. Schoenberg has no real value as far as I'm concerned merely as the basis of the 12-tone method. He means something because he speaks with the intensity \& rasping tone of the prophet crying out in the wilderness. Even the gentler Webern has a kind of white heat, a concentration of condensation which cuts its way into the soul \& enriches the heart. Well, never mind my raving \& ranting. I simply can't take my music calmly-objectively.5

Rochberg's last strictly twelve-tone work was the First Piano Trio (1962-3). In the summer of 1963, during the final stages of its composition, he seemed to know that he had reached an impasse for, in a letter of 1 July of that year, he confided in Anhalt:

I know that this is the last piece I will write in this particular way. I want to get on to do something else that is brewing, i.e., a different point of view, a different angle of approach. How tired I'm getting of complex surfaces. I

5 George Rochberg to Istvan Anhalt, letter of 9 September 1961, in Gillmor, Eagle Minds, 5-6.

The works in question were Babbitt's Vision and Prayer (1961), Carter's Double Concerto for Harpsichord, Piano and Two Chamber Orchestras (1961), and Kirchner's Concerto for Violin, Violoncello, Ten Winds, and Percussion (1960).

Duende literally means "imp," "goblin," or "demon"; for Lorca, duende is the "mysterious power" of great art: "'All that has dark sounds has duende.' And there is no greater truth. These dark sounds are the mystery, the roots pushing into the soil which we all know, which we all ignore, but from which comes what is real in art... Angel and muse come from outside; the angel gives light and the muse gives shape ... The duende, though, must be awakened in the deepest dwellings of blood." From the text of a lecture the poet gave in Havana and Buenos Aires in 1933, "Theory and Function of the Duende," in Federico Garcia Lorca, Selected Poems, trans. Merryn Williams (Newcastle upon Tyne: Bloodaxe Books, 1992), 219-30. 
long for the ability to make simple, direct statements \& bury the complexities below the surface where only I will know they exist or perhaps a few sympathetic souls will care to burrow for nuggets, if any exist, that is! ${ }^{6}$

It is evident, however, that Rochberg's disillusionment with serialism-in particular, total (or integral) serialism - had been incubating for several years before that. As early as 1957, in a review of Pierre Boulez's two-piano work Structures (Book 1), he touched on a theme that would haunt many of his later public (and private) statements: he charged the French composer with disregarding the non-rational side of the human spirit, with substituting a "remarkable cerebration" for "a deeply felt creative necessity." F Fifteen years later, Boulez would become the target of one of Rochberg's most celebrated aphorisms: "The past refuses to be erased. Unlike Boulez, I will not praise amnesia." ${ }^{8}$

In a 1959 essay Rochberg argued that a completely rationalized system of composition ("total organization") is incapable of mirroring subjective experience, for it tends to divorce the composer from the composition while impairing the equilibrium between musical structure and its perception. ${ }^{9} \mathrm{He}$ refined the argument in 1960, in one of the first essays to explore his longstanding fascination with the concepts of time and space in music-the relationship between duration and existence and the roles of memory, identity, intuition, and perception in the shaping of human experience. ${ }^{10}$ Commenting on the two dominant approaches to high-culture music in the first two decades of the post-1945 era, Rochberg identified a problem common to both. Although seemingly polar opposites in their approaches to the organization (or nonorganization) of sound, both total serialism and chance music, in Rochberg's view, are inherently incapable of projecting the three-dimensionality of time perception-past, present, and future-in artistically meaningful ways. For Rochberg, serialism was chiefly a syntax, not a language. ${ }^{11}$

Certain limitations in modern music_chance music or its putative opposite, serialism-have emerged over the intervening years since its heyday. Chance music, associated in particular with John Cage and his disciples, seems content

6 Rochberg to Anhalt, letter of 1 July 1963, in Gillmor, Eagle Minds, 22.

7 Rochberg, "Pierre Boulez: Structures," Notes 14, no. 2 (March 1957): 197. It is interesting to note that Boulez would write, some thirty years after the composition of Structures, that great art was "a mixture of the rational and the irrational; the two are like a knot that is impossible to untie." "The Composer and Creativity," Journal of the Arnold Schoenberg Institute 11, no. 2 (November 1988): 122.

8 Rochberg, "Reflections on the Renewal of Music," Current Musicology 13 (1972): 76; reprinted in Rochberg, The Aesthetics of Survival: A Composer's View of Twentieth-Century Music, ed. with intro. by William Bolcom (Ann Arbor: University of Michigan Press, 1984), 233. As a kind of corollary to Rochberg's aphorism, we might add the following statement by neuroscientist Daniel Levitin: "Memory affects the music-listening experience so profoundly that it would not be hyperbole to say that without memory there would be no music." Daniel J. Levitin, This Is Your Brain on Music: The Science of a Human Obsession (New York: Dutton, 2006), 162-3.

9 See Rochberg, "Indeterminacy in the New Music," Score 26 (January 1960): 9-19; reprinted in Rochberg, Aesthetics of Survival, 3-15.

10 See Rochberg, "Duration in Music," in The Modern Composer and His World, ed. John Beckwith and Udo Kasemets (Toronto: University of Toronto Press, 1961), 56-64; reprinted in Rochberg, Aesthetics of Survival, $71-7$.

11 Ibid. 
to accept a continuous Zen-like present as sufficient in itself, to which might be added Stanley Cavell's observation that "speaking through chance foregoes a voice altogether-there is nothing to say." ${ }^{2}$ Total serialism, on the other hand, by objectifying duration, is similarly restricted by allowing its form-giving properties to be compromised. In short, it fails to provide an organic threedimensional model of duration as experienced through the human perception of time: past (memory) and future (anticipation) become conflated into a continuous present, and the crucial balance between information and redundancy has malfunctioned. (Could this be one of the reasons why many listeners report a strong family resemblance between total serialism and chance music?) A homogeneity of dissonant texture results in a kind of harmonic stasis or entropy. When temporality is compromised, the perception of musical form is subverted, replaced by a continuous circle of illusory space, of flux and eternal becoming.

As Rochberg observed, such space-form music "no longer exists in its former state of anticipation of the future. It projects itself as a series of present moments, holding up to aural perception each spatial image as the self-sufficient object of perception as it occurs, not as it will realize itself in some future event."13 And further, "The suprarationalism of total serial music defeats the durational process in the end; that is to say, it does not engage the listener in his most profound intuitive relation to life and experience, through his grasp of duration by means of which he creates and recreates the order of his personal identity and therein finds his being." 14 Rochberg found reinforcement for his position in the writings of the anthropologist Claude Lévi-Strauss, who argues that serialism is a "secondary" language, severed from its intuitive roots; it attempts "to construct a system of signs on a single level of articulation" by subverting those "general structures whose universality allows the encoding and decoding of individual messages." 15 That is to say, if culture is a system of symbolic communication, meaning is impaired when signifiers are not rooted in general structures that define tradition and create fundamental conditions of communication. Following from this, Lévi-Strauss formulates his critique of serialism by relying on a poetic marine metaphor, one that will resonate with the vast majority who, figuratively, feel at sea in the presence of much serial music:

Only ideologically can the [serial] system be compared to a language, since unlike articulate speech, which is inseparable from its physiological or even physical foundation, it is a system adrift, after cutting the cables by which it was attached. It is like a sailless ship, driven out to sea by its captain, who has grown tired of its being used only as a pontoon, and who

12 Stanley Cavell, "Music Discomposed," in Art, Mind, and Religion: Proceedings of the 1965 Oberlin Colloquium in Philosophy, ed. W. H. Capitan and D. D. Merrill (Pittsburgh: University of Pittsburgh Press, 1967), 88-9.

13 Rochberg, "The Concepts of Musical Time and Space," in Aesthetics of Survival, 132.

14 Rochberg, "Duration in Music," 67.

15 Claude Lévi-Strauss, The Raw and the Cooked: Introduction to a Science of Mythology I, trans. John and Doreen Weightman (New York: Harper \& Row, 1969), 24. 
is privately convinced that by subjecting life aboard to the rules of an elaborate protocol, he will prevent the crew from thinking nostalgically either of their home port or of their ultimate destination. ${ }^{16}$

In an article first published in 1973, Rochberg recorded his reaction to LéviStrauss, concluding that his "formulation, while not historical, points up the real consequences of Schoenberg's act of wrenching himself loose from, but not free of, that general structure which defines tradition-that slow, invisible process of accretion through which 'real but unconscious relations' work their way up and through generations of human beings."17 Put another way, the mind is not a tabula rasa (as psycholinguist and social activist Noam Chomsky reminds us) $;{ }^{18}$ there must be a shared field of experience between the composer and the listener at some level of cognition if meaningful communication is to take place. Many years later Rochberg related in a letter to Anhalt:

The closest to a possibly convincing analogy between so-called science \& music occurs in the preface or introduction to Claude Lévi-Strauss's The Raw and the Cooked where he argues that a "secondary" language cut off from intuitive roots is an arbitrary thing, has no hope of survival, is not sufficiently anchored in the reality of the mysteries of the neurological makeup of man to secure it to ongoing cultural values ... 12-tone or what everyone loves to call it, serialism, is a "secondary" language. True believers notwithstanding, ordered chromaticism plus any extensions into the genuinely unmeasurable such as texture, timbre, dynamics ( $p p p-f f f$ ), even metrics which involves speed designations (fast: how fast is fast? slow: how slow is slow?) - that's what I mean by unmeasurable-hit the rocks \& reefs of an uncontrollable energy called "the sea" a long time ago. ${ }^{19}$ (emphases in original)

As a corollary to Lévi-Strauss's position-clearly shared by Rochberg-it might be helpful to add Rose Rosengard Subnotnik's observation concerning

16 Ibid., 25.

17 Rochberg, "Reflections on Schoenberg," Perspectives of New Music 11, no. 2 (Spring-Summer 1973): 77; reprinted in Rochberg, Aesthetics of Survival, 63.

18 See, for example, Chomsky, Syntactic Structures (The Hague: Mouton, 1965).

19 Rochberg to Anhalt, letter of 30 April 2000, Istvan Anhalt Fonds (MUS 164), Music Division, Library and Archives Canada, Ottawa. The extensive correspondence between Rochberg and Anhalt-nearly four hundred letters written between 1961 and 2005-are divided mainly between Library and Archives Canada and the George Rochberg Collection of the Paul Sacher Foundation in Basel, Switzerland. A selection of 252 of these letters appears in Gillmor, Eagle Minds.

It should be noted that Lévi-Strauss's structuralist approach to the problem of serialism has its critics. Morag Grant, for example, questions his assumption that musical and spoken languages function analogously on primary and secondary levels of articulation. In her view, such a binary system of communication fails to take into account the distinctions between open (serial) and closed (thematic) musical systems as well as aesthetic and semantic modes of information. Moreover, by insisting upon "the articulatory power of hierarchies," Grant suggests, Lévi-Strauss risks placing himself in the unenviable position of rejecting not only serial music (with all its unlovely connotations in the popular mind) but also a great deal of music that belongs to a parallel stream of early modernism: Debussy's more athematic, tonally ambiguous, and formally amorphous piano Préludes, for example. M. J. Grant, Serial Music, Serial Aesthetics: Compositional Theory in Post-War Europe (Cambridge: Cambridge University Press, 2001), 212-3. 
the social failure of a great deal of modernist music, that the musical significance of much contemporary high-culture music is located literally and exclusively in the individualized and often cryptic structure of the work, "to the point where it is protected against even the simple social activity of comprehending"; and she traces this attitude back to Schoenberg, for whom "the idea,' as prior to sound and style, generates and indeed is 'the totality of a piece" 20 (emphases in original). Indeed, as random encounters with such academic journals as Perspectives of New Music and Journal of Music Theory reveal, more often than not, the new music is not to be judged qualitatively by its sound-a subjective surface appeal that resists "objective" analysisbut rather quantitatively on the basis of its numerical and graphic substructure: the triumph of the eye over the ear or, in Ivesian terms, "manner" over "substance." ${ }^{21}$ Is it any wonder that many critics have tended to mistake the system for the product?

Die-hard serialists are quick to point out that serialism is a technique, not a musical language, and therefore lends itself to the same stylistic range as tonal music. And this is essentially true. One can point to the dramatically different sound worlds of the major founding troika-Schoenberg, Berg, and Webern-as evidence. However, these three composers do have one thing in common: their music, for a wide spectrum of the listening public, tends to be disorienting and alienating. Coming into being in a post-Freudian "age of anxiety," atonalism and its serialist offspring became powerful expressive tools in an "expressionist" era intent on exploring the darker regions of the human psyche. In such enduring icons of modernism as Erwartung and Survivor from Warsaw, there is a perfect fusion of idiom and extra-musical content; one is hard-pressed to imagine such dark and disturbing emotions expressed in any other manner. Atonality, whether serialized or not, breathed from the outset the "air of another planet" and provided composers with the means to express the hitherto inexpressible.

Umberto Eco makes one of the most eloquent arguments for the necessity of new musical languages, in this case serialism, by making a distinction between "structural thought" and "serial thought":

The main goal of serial thought is to allow codes to evolve historically and to discover new ones, rather than to trace them back to the original generative Code (the Structure). Thus, serial thought aims at the production of history and not at the rediscovery, beneath history, of the atemporal abscissae of all possible communication. In other words, the aim of structural thought is to discover, whereas that of serial thought is to produce. ${ }^{22}$ (emphases in original)

\footnotetext{
20 Rose Rosengard Subotnik, "The Challenge of Contemporary Music," in Developing Variations (Minneapolis: University of Minnesota Press, 1991), 270-1, 275.

21 See Charles Ives, Essays before a Sonata, the Majority, and Other Writings, ed. Howard Boatwright (New York: Norton, 1962), esp. 75-7.

22 Umberto Eco, The Open Work, trans. Anna Cancogni, intro. David Robey (Cambridge, MA: Harvard University Press, 1989), 220-1. There is, of course, an extensive literature, both pro and con, on the viability of serialism. On the negative side of the ledger, William Thomson requires an entire
} 
Such a statement strongly indicates a rejection of Lévi-Strauss's structuralist thought, his notion of a double articulation of linguistic systems, which implies that there are universal underlying principles in operation. Rather, Eco finds that the very strength of serialism is its capacity to generate new forms of communication, new structural realities. However, even if Rochberg had known the work of Eco-and there is no evidence of this-one can speculate that Eco's arguments would not have swayed him, largely on the grounds that they do not address the layered roles of memory, continuity, and tradition in the construction of meaning.

Rochberg's rejection of modernism, in particular that sub-creed of modernism known as serialism, resulted in a veritable flood of critical commentary. At their most vigorous, these critiques move perilously close to the ad hominem, as in the vitriolic exchange between Jonathan Kramer and Rochberg that took place in the pages of Critical Inquiry in 1984-5. In December 1984, Rochberg published an article titled "Can the Arts Survive Modernism?" to which Kramer fired back with "Can Modernism Survive George Rochberg?" Rochberg responded in the March 1985 issue with his "Critical Response: Kramer versus Kramer," an obvious reference to the eponymous 1979 film starring Dustin Hoffman and Meryl Streep, a gritty drama of child custody that won the Oscar for Best Picture that year. ${ }^{23}$ This is not the proper place to reopen the "modernist/postmodernist" debate as it relates to music, which was generated-at least in America-to a great extent by Rochberg's music and writings. But a brief overview of the exchange between Kramer and Rochberg will provide a useful summary of some of the key issues.

Although the notoriously slippery term postmodernism often appears in reference to Rochberg's post-serial music, it should be noted that the composer rejected the validity of the label. As he wrote to Anhalt, it is "a term I have no personal use for!" 24 For Rochberg, a term that incorporates modernism is objectionable on semantic grounds, if only because it would keep alive the memory of a discredited artistic movement and serve as "a constant reminder of the sickness of spirit which the modern movement engendered, of the loss of values it brought on, of the imbalances it caused." 25 The search for a more bal-

\footnotetext{
monograph to defend his bluntly stated thesis: "Whatever posterity may determine to have been the merit of his [Schoenberg's] innovations as a composer, the rationale he devised for his music was derived from untenable hypotheses." Schoenberg's Error (Philadelphia: University of Pennsylvania Press, 1991), 37. No less a champion of Schoenberg than Glenn Gould declared in a 1963 lecture at the College-Conservatory of Music of the University of Cincinnati that the "fundamental effect" of Schoenberg's soundworld "has been to separate audience and composer. One doesn't like to admit this, but it is true nonetheless." Glenn Gould, Arnold Schoenberg: A Perspective, foreword Arthur Darack (Cincinnati: University of Cincinnati Press, 1964), 17; reprinted in The Glenn Gould Reader, ed. with intro. by Tim Page (New York: Knopf, 1984), 119.

23 Rochberg, "Can the Arts Survive Modernism? (A Discussion of the Characteristics, History, and Legacy of Modernism)," Critical Inquiry 11 (December 1984): 317-40; Jonathan D. Kramer, “Can Modernism Survive George Rochberg?" Critical Inquiry 11 (December 1984): 341-54; Rochberg, “Critical Response: Kramer vs. Kramer," Critical Inquiry 11 (March 1985): 509-17.

24 Rochberg to Anhalt, letter of 20 May 1984, in Gillmor, Eagle Minds, 141.

25 Rochberg, "Can the Arts Survive Modernism?" 332.
} 
anced culture requires a solution more profound than the scattered pluralism and relativism offered by the postmodernists. ${ }^{26}$

Rochberg's objections aside, it is indeed regrettable that such an oxymoronic and polysemous term has become firmly entrenched in the discourse of critical theory. As David Harvey notes, the term is "a mine-field of conflicting notions" and should have disappeared "under the weight of its own incoherence." 27 To be sure, all attempts at labelling complex cultural movements are fraught with difficulties, but postmodernism seems to occupy a special niche in the lexicon as one of the most elusive and imprecise of terms. It will be understood in this context in the general sense of a sociocultural attitude rather than in the narrower sense of a specific artistic trend or style. Just as Gertrude Stein referred memorably to the First World War as the first cubist war, ${ }^{28}$ one could suggest that a "postmodern consciousness" is a chronic condition in the global village, a kind of cubist vision writ large of a technology-saturated world in which we attempt to negotiate a path through a multiplicity of polarities-fragmentation and homogeneity, eclecticism and innovation, unity and disunity, continuity and simultaneity, local community and globalization, order and freedom, faith and reason, high culture and low-a jangle of sounds and images flooding cyberspace, not to speak of urban space, in an unrelenting bombardment of the senses, a world in which mass advertising has become the capitalist art form par excellence. Little wonder that a single label should be incapable of encapsulating such a fractured and disoriented society as ours, a "moronic inferno," in Saul Bellow's tragi-comic metaphor, ${ }^{29}$ an endless carnival of crassness and banality that induces cultural amnesia. Postmodernism, in this sense, can perhaps best be seen as a symptom of a technocratic society, of cultural pathology, a pessimistic expression of a generation's sense of uncertainty and foreboding. In the end, however, perhaps it is best simply to surrender and agree with Alex Ross that "'modernism' is already so equivocal a term that to affix a 'post' pushes it over the edge into meaninglessness."30

${ }^{26}$ For an extended discussion of Rochberg and postmodernism, see James Wierzbicki, "Reflections on Rochberg and 'Postmodernism,'” Perspectives of New Music 45, no. 2 (Summer 2007): 108-32.

27 David Harvey, The Condition of Postmodernity: An Enquiry into the Origins of Cultural Change (Cambridge, MA: Blackwell, 1990), viii.

28 See Gertrude Stein, Picasso (1938; repr. Boston: Beacon, 1959), 11.

29 See, for example, Humboldt's Gift (1975). Bellow borrowed the expression from the British painter, novelist, and critic Wyndham Lewis (1882-1957), for whom it was a symbol of a confused, decadent, and apathetic postwar Western European society-a vulgar mass of dead minds, of somnambulist automata, a "moronic inferno of insipidity and decay." Rude Assignment: A Narrative of My Career Up-to-Date (London: Hutchinson, 1950), 169. It thus offered Bellow an appropriate and vivid metaphor for what he perceived to be the corruption, dehumanization, and shallowness of contemporary American society. As Martin Amis reminds us, however, "The moronic inferno is not a peculiarly American condition. It is global and perhaps eternal. It is also, of course, primarily a metaphor, a metaphor for human infamy: mass, gross, ever-distracting human infamy . . . It exactly describes a possible future, one in which the moronic inferno will cease to be a metaphor and will become a reality: the only reality." The Moronic Inferno and Other Visits to America (New York: Viking Penguin, 1987), x-xi.

30 Alex Ross, The Rest Is Noise: Listening to the Twentieth Century (New York: Farrar, Straus and Giroux, 2007), 215. 
Rochberg's analysis of modernism, in his opening salvo for Critical Inquiry, ranges far beyond music itself, which he sees as only a part of a variegated pattern of cultural thinking that permeated nearly every corner of twentiethcentury life. Central to his argument is what he called the "metaphysical gap," deriving in large part from Wittgenstein's proposition that ethical and aesthetic judgments (one and the same thing for the Austrian philosopher) lie outside the property of language, that those questions of value that matter most in human life are immune to the descriptive powers of language, are beyond the limits of the "sayable." Any discussion of values, therefore, must be consigned to the realm of "nonsense," albeit important nonsense. Better yet, Wittgenstein famously admonished, "Whereof one cannot speak, thereof one must be silent." 31 Art, however, need not be silent, for it is the bridge between language and silence and it embodies its own intrinsic value. Rochberg recognized that the "metaphysical gap between human consciousness and cosmos" is as old as recorded history and saw it as "the primary source and cause of human uncertainty," 32 a void that traditionally has been filled by art. By attempting to deny memory, history, and tradition, modernism succeeded in negating previous attempts to bridge the gap, leaving in its wake a deeper gulf than ever before. But we persist in reaching across the divide in our attempts to rediscover the true nature of things-as opposed to mere technological devices-in short, to reconnect with "the continuity of civilization and its enduring values." 33

Rochberg outlined three stages in the evolution of modernism: an Age of Gold and Silver (roughly 1900-14), a Bronze Age (1918-39), and an Iron Age (1945-ca. 1970). The last he saw as largely an American phenomenon, fuelled by the universities, which, especially after the Second World War, embraced artists of all kinds, native-born and émigré alike, in record numbers. Academia became a necessary refuge for the dreamers in a highly utilitarian society that has from the beginning tended to view art-as opposed to entertainment-as non-essential. Such insularity would signal the death knell of modernism, in Rochberg's view, as the cloistered isolation of the "ivy" tower bred (and inbred) a pseudo-scientific art at the extreme end of the "high-art" spectrum, a rarefied and hermetic art increasingly divorced from the outside world and seemingly oblivious to "the hungers of the human spirit."34 Ironically, many of those American composers who lived through the Iron Age largely independent of the academy have flooded back into a fairly broad public consciousness in a way that lingering, rusting Iron Age modernists can only envy, if indeed they actually care.

Clearly, Jonathan Kramer was one who did care, for it would appear that Rochberg's essay hit a nerve. Kramer's is an uneven piece of work, contradictory in parts, off topic in others. It is odd that a polemic purporting to be a critical response to another polemic should begin by denying the validity of

${ }^{31}$ Ludwig Wittgenstein, Tractatus Logico-Philosophicus, trans. Cecil K. Ogden and Frank P. Ramsey, intro. Bertrand Russell (London: Routledge \& Kegan Paul, 1922), 189.

32 Rochberg, "Can the Arts Survive Modernism?" 336-7.

33 Ibid., 320 .

34 Ibid., 331. 
artists expressing themselves in prose on the grounds that art does not obey aesthetic dictates. If this is true, then Kramer has nothing to fear. But he contradicts himself early on by claiming that "only trivial art slavishly obeys aesthetic decrees," 35 a derogatory remark that could be construed, judging from the context, as linking Rochberg the composer with the more tawdry products of Soviet Socialist Realism..$^{36}$ Whereas Rochberg ranges widely across the history of ideas, Kramer insists on keeping music the focus of his arguments. $\mathrm{He}$ approaches the ad hominem in basing his critical response not so much on Rochberg's arguments per se as on his music. Suggesting that Rochberg was never really a modernist because he came to serialism late, he implies, in a curious lapse of logic, that the older composer is therefore an untrustworthy critic of modernism, concluding that "neither Rochberg nor anyone else can legislate art ... Art does what it does for deeper causes than polemicists' rantings." 37

In his "Critical Response," Rochberg took Kramer to task on several grounds: "the endemic disarray of his thought process," 38 his slipshod use of language, his inability (or refusal) to grasp the larger dimensions of Rochberg's approach to a complex problem, and, finally, his unfortunate tendency to use Rochberg's music as a kind of club with which to beat him. As if berating a muddled graduate student, he concluded:

I find it odd in the extreme and not a little amusing that he [Kramer] interprets my critical view of modernism as some kind of personal threat to modernism itself and/or as a form of already imposed or imminently impending "legislation." Perhaps he senses or possibly fears the truth of what I have said and, in trying to defend his own incoherent and questionable position, has resorted to unseemly and unpalatable tactics. His scatter-shot attempt at a response is a far more convincing indictment of the jumbled ideology of present-day modernism than any I could ever have devised. ${ }^{39}$

Privately, Rochberg confided to Anhalt that "the 'controversy' was engineered by the editor of Critical Inquiry. I have no objection to that per se but the level of discussion to be worthwhile is not 'high' enough, my respondent, one Jonathan Kramer, having seen fit to make his piece a personal attack on me." In addition, he noted with a tone of sad resignation, "I've never really understood why academic 'discussion' gets so acrimonious."40 Finally, on 23 April 1985, he

35 Kramer, "Can Modernism Survive George Rochberg?" 342.

${ }^{36}$ It would appear to be no mere coincidence that the modernist project, which highly prized experimentation and originality in its search for a singular underlying reality-essential components of capitalist notions of creative liberty, individualism, and entrepreneurship-reached the apex of institutional acceptance during the height of the Cold War. If there is indeed a link, there is a certain irony in the fact that the Soviet Union was not alone in aestheticizing politics, albeit with far less subtlety. See, for example, Serge Guilbaut, How New York Stole the Idea of Modern Art: Abstract Expressionism, Freedom, and the Cold War, trans. Arthur Goldhammer (Chicago: University of Chicago Press, 1983).

37 Kramer, "Can Modernism Survive George Rochberg?" 353.

38 Rochberg, "Critical Response," 509.

39 Ibid., 517.

40 Rochberg to Anhalt, letter of 15 January 1985, in Gillmor, Eagle Minds, 157. 
wrote to Anhalt, “Perhaps you've gotten hold of Kramer's 'reply'-which will make reading my response to him more meaningful-especially in 'explaining' the tone I adopt toward him. In point of fact if I were a modernist loyalist myself he is the last person in the world I'd want defending what I believed in" 41 (emphases in original).

Now, nearly a quarter century later, it seems at least mildly ironical to note that Kramer, a professor of composition and theory mostly at Columbia University, toward the end of his creative life moved away from "a highly structured serial language" in an attempt in his later compositions "to reconcile a tendency toward musical calculation with the more intuitive side of his personality," 42 a statement that suggests, if not a wholesale rejection of "academic" modernism, at least a softening of attitude. And of course the past few decades have seen the coming-of-age of a generation of composers in North America (and elsewhere) of various stripes who have made significant inroads in reclaiming audiences who had long rejected the role of victims of modernist arrogance, simply refusing to be manipulated, to engage in the dialectic. After all, silence is a form of resistance. Would it be unseemly to suggest that musical modernism, at least in its most ratiocinative and dogmatic form, did not in fact survive George Rochberg? Of course, he is by no means alone, for a significant number of composers of roughly his generation, both in North America and abroad, followed a very similar path.

The remainder of this essay appraises Rochberg's engagement with modernism and postmodernism and its controversies in the light of recent Rochberg criticism, the continuity to be observed throughout his work, and the perspective on modernism, serialism in particular, that a century's distance affords. The modernist/postmodernist debate often becomes acrimonious, almost to the point of parody. The modernists tend to lump the postmodernists together as simplistic popularizers with an overweening adolescent need to be loved, who disguise a lack of real musical substance with repetitive rhythms, creamy homogenized textures, and overripe orchestration, while the postmodernists tend to see the older generation as insular and puritanical academicians tenaciously holding on to jaded techniques and principles as if complexity were a badge of honour and communication and social engagement distasteful if not downright sinful. Not one known for her temperate views, Susan McClary paints a vivid picture: "We are back to the Fall of Rome with the barbarians at the gates; we are encouraged to perceive the serious composer as an endangered species and to provide public subsidies underwriting music that most proudly announces itself as incomprehensible." 43 What we are seeing, of course, is in many respects yet another variation of the "generation gap." The modernists make the mistake of assuming that anti-modernism equals anti-intellectualism and that "accessibility" and "simplicity" are synonyms, while the postmodernists indulge in an even more grievous error by assuming-or so it

41 Rochberg to Anhalt, letter of 23 April 1985, in Gillmor, Eagle Minds, 163.

42 The New Grove Dictionary of American Music, s.v. "Kramer, Jonathan D" (by James Chute).

43 Susan McClary, "Terminal Prestige: The Case of Avant-Garde Music Composition," Cultural Critique 12 (Spring 1989): 63. 
seems - that the validity of the new discourse automatically invalidates the old. Implicit in much of the debate is the modernist assumption that postmodernism is restricted mainly to some form of minimalism, and that minimalism itself is little more than a form of Muzak writ large. On the other side, the postmodernists drag out the same handful of victims for scorn-Babbitt and Boulez are favourite targets-as if modernism did not exist outside some form of total serialism. If the modernists tend to isolate music as an autonomous, objective, and abstract art in order to protect it from "cultural populism and passing fashion," 44 the postmodernists, in their zeal to connect music to sociopolitical agendas, tend to transform the study of music into what Pieter van den Toorn has called "a kind of musicology of resentment" 45 (emphasis in original). And so it goes. As Alex Ross reminds us, the debate between ars modernorum and ars antiqua is nothing new; it is centuries old. "Composition," he concludes, "only gains power from failing to decide the eternal dispute. In a decentered culture, it has a chance to play a kind of godfather role, able to assimilate anything new because it has assimilated everything in the past." 46

One of the most balanced critiques of Rochberg's "postmodernism" comes from Richard Taruskin. By evoking the styles of the old "master narrative" through pastiche, he argues, Rochberg was doomed to produce merely simulacra of emotions; that is to say, it is difficult, if not impossible, to borrow a historical style without also inheriting the emotional field that is embedded in it. Whose "heartfelt emotions" are we experiencing? Can such music legitimately speak to or reflect contemporary experience or is it nothing more than delusional nostalgia? As Taruskin eloquently puts it (with a nod to Baudrillard):

The implication is indeed depressing: just as we can communicate artistically only through the studied simulacra of styles that were once spontaneous, so our emotions themselves have become simulacra. Rochberg's quest to regain the full range of sincere emotional expression that had been available to artists (and other humans) before the horrors of the twentieth century is thus doomed to failure: but the failure is noble, because it faces the unhappy truth of contemporary life rather than retreating, as modernism had done, into a self-satisfied, self-induced (and socially isolating) delusion of freedom. "Postmodernism," in this view, means resignation to (or making the best of) a state of diminished capacity. ${ }^{47}$

As perceptive as Taruskin's conclusions are, one wonders if he, like many before him, does not tend to rely too heavily on Rochberg's early "collage" works, such as Music for the Magic Theater (1965), or the more blatant "forgeries"-as some would claim—such as the third movement of the Third String Quartet

44 Milton Babbitt, "The Unlikely Survival of Serious Music," in Milton Babbitt: Words About Music, ed. Stephen Dembski and Joseph N. Straus (Madison: University of Wisconsin Press, 1987), 163.

45 Pieter C. van den Toorn, Music, Politics, and the Academy (Berkeley: University of California Press, 1995), 61.

46 Ross, The Rest Is Noise, 543.

47 Richard Taruskin, "After Everything: Postmodernism: Rochberg, Crumb, Lerdahl, Schnittke," The Oxford History of Western Music (New York: Oxford University Press, 2005), 5:435. 
(1971-2), works that figure prominently in almost every critique of the composer's music, including Taruskin's. We need to remind ourselves that Rochberg's "time of turning," 48 as he put it, was not centred on a wholesale repudiation of all forms of musical modernism but was aimed, more specifically, at the repressive hegemony of serialism in the academy-especially in the northeastern United States where he was based-during the very period in the early 1960 s when he began his rebellion. Moreover, it is arguable that Rochberg's wholesale embracing of historical styles in the 1960 and 1970 s was a necessary stage in his musical evolution - a kind of exorcism - as he strove to reinvent himself. That the composer himself clearly recognized the futility of continuing along this path we learn from a 1986 interview with the American conductor Richard Dufallo: "So it's no longer a matter of speaking, or trying to speak the language of Beethoven ... which I did in my Third Quartet. Some people absolutely delighted in it and some absolutely abominated it, because I spoke directly in the language of the 19th century. I can't do that anymore. When I did it, I believed it was possible. Now, I don't believe in its efficacy any longer ... in its rightness ... and if I have that feeling, I must go on"49 (ellipses in original).

In this regard, it is instructive to compare the three piano trios (1962-3, 1985, 1990).50 Those with an intimate knowledge of Rochberg's music will recognize the composer's voice in all three of these disparate works, which conveniently mark three distinct stages in his musical evolution. The first is a twelve-tone piece that, while inhabiting the rather generic sound world of much serial composition of the period, is a work of nervous intensity and a kind of crystalline lyricism, a legacy, perhaps, of his association with Luigi Dallapiccola while on a Fulbright Fellowship in Rome in the early 1950s. The second is frankly tonal and grandly romantic in its gestures, therefore bordering on the very kind of pastiche that has tarnished Rochberg's reputation in some quarters. The final trio is, in a very real sense, a kind of masterly synthesis of the two styles and transcends them both. It is, in this writer's estimation, by far the finest of the three, a work that manages to speak unselfconsciously and with a craggy lyricism and emotional intensity very much its own. The composer also preferred the third trio; considering the three pieces as a group, however, he also took pleasure in their "linguistic and emotional differences. They 'bounce' off each other even while confirming the same personality or voice expressed in widely different gestures and 'tones of voice"'51 (emphasis in original). It is interesting to note that Istvan Anhalt also sensed the superiority of Rochberg's final piano trio, and his response to his friend's music is worth noting:

Very strong music this, George, and it would need thousands of words to describe the thoughts \& feelings which it inspired. I said "strong," and

48 Rochberg, liner note for the 1973 recording of the Third String Quartet (Nonesuch H-71283); reprinted in Dixon, George Rochberg, 141.

49 Rochberg, quoted in Richard Dufallo, Trackings: Composers Speak with Richard Dufallo (New York: Oxford University Press, 1989), 72.

50 The Kapell Trio, Rochberg: The Three Piano Trios, Gasparo Records (Gasparo GSCD-289) (1998).

51 Rochberg to the author, letter of 2 November 1998. 
now I add: beautiful, moving, persuasive, wonderfully fluent in language and more. Perhaps the last work (1990) represents the "peak" for me; the language is "integrated," almost a Rochbergian "vernacular," so personal is it. "Style" no longer is in question; there is a convincing discourse. The articulation of the movements, character, lengths, etc. are all "in one piece" here. Of course, the "burden" is in the minute details: the "natural flow" of counterpoint, the trouvailles of the harmonic colour \& flow, the generosity of silence (here) and the "stilling" of the dynamic from the rhetorical ff to the whisper-like $p p$. All in all: very persuasive piece the 1990 Trio. ${ }^{22}$

If many of Rochberg's early post-serial works, with their elements of pastiche and collage, playfulness, irony, and a kind of schizoid heterogeneity (whether intended or not), can be seen to fit some generally accepted definitions of postmodernism, the later works-of which the Piano Trio No. 3 is an excellent example-seem to inhabit a world apart from postmodernism. In any event, there are signs that we may be moving beyond it. Perhaps a future generation of historians will look back on postmodernism as a rather brief rococo-like transition period. Even though there may no longer be a single truth, with all the repression that potentially flows from such an Enlightenment utopian ideal, we still have to make choices, and we do not do this arbitrarily. Although we may have slain the notion of the meta-narrative, the postmodernist project nevertheless provokes the question: whose pluralism?

In a 1995 essay I argued that atonality, whether free or serialized, is a language of instability, and therefore, in psychological terms, of abnormality, and that as such it is most effective when used in conjunction with other gestures, such as tonal stability, to suggest contrasting mental states. ${ }^{33}$ Passages from two iconic twentieth-century dramatic works might be cited as compelling evidence. In act 3 of Wozzeck, Berg reveals his deep empathy with his pathetic Kafkaesque hero through a great Mahlerian dirge of painful intensity-in D minor. Conversely, two decades later Britten depicts the mental collapse of Peter Grimes in a chilling passage of fragmented, unmetred snippets teetering on the edge of atonality, tenuously hanging on to a tonal base only through the ghostly presence of the dominant seventh pedal in the horns, which peer ominously through the fog underlying the distant chorus's recurring "Grimes, Peter Grimes." As a kind of corollary to these examples, it is important to note that Schoenberg's dramatic, or programmatic, works, with their externally driven "meaning," or psychological subtexts, have garnered comparatively greater public acceptance than his non-texted, or abstract, works.

Expressionism is an artistic movement that has as its philosophical parallel nihilism. In it lies a concentrated, almost barbaric, power, but also the seeds of madness. It is an art of pessimism, of anxiety and decay, of existentialist angst. It speaks to the spiritual exhaustion of a society. Atonality is its primary musical mirror. Writing in the early years of the First World War, the

52 Anhalt to Rochberg, letter of 29 October 1998, Istvan Anhalt Fonds (MUS 164), Music Division, Library and Archives Canada.

53 See Alan Gillmor, "Echoes of Time and the River," in Taking a Stand: Essays in Honour of John Beckwith, ed. Timothy J. McGee (Toronto: University of Toronto Press, 1995), 24. 
Austrian playwright and critic Hermann Bahr provided a sinister definition of Expressionism:

Never yet has any period been so shaken by horror, by such a fear of death. Never has the world been so silent, silent as the grave. Never has man been more insignificant. Never has he felt so nervous. Never was happiness so unattainable and freedom so dead. Distress cries aloud; man cries out for his soul; this whole pregnant time is one great cry of anguish. Art too joins in, into the great darkness she too calls for help, she cries to the spirit: this is Expressionism. ${ }^{54}$

If we add to this Karl Kraus's portentous observation that turn-of-the-century Vienna was an "experimental station for the end of the world," 55 the picture becomes even more disturbing. Even a cursory survey of the works of the Second Viennese School reveals a marked similarity of extra-musical theme: psychological disorientation and deterioration, alienation and isolation, sexual pathology and libidinal fantasy. Like the haunted, staring eyes of a Schoenberg self-portrait, the expressionists peered into the abyss, into the depths of their own naked souls. For Thomas Harrison, the "content" of expressionist music is "form unhinged from all content whatsoever-forms of pure sound in its unmitigated and alien materiality." If this music has any emotional purpose, he concludes, "it is certainly not solace, consolation, joy, or reassurance. It is something closer to the unsettled, inexplicable emotions of turmoil, agitation, and unease." 56 As Adorno would have it, loneliness had found its style: "In Schoenberg, everything is based upon that lonely subjectivity which withdraws into itself." 57 Paradoxically, at the same time that it dramatically widened the expressive range of music, atonality tended to narrow it by channelling it into a single "daemonic" space. Film music is an art form that, usually, allies music with dramatic situation quite directly. In this regard it is interesting to note that Leonard Rosenman's score for The Cobweb (1955), which centres on the staff and inmates of a psychiatric institution, has the distinction of being the first serial film score. "Rosenman employed this compositional style, as many later film composers did," notes Joseph N. Straus, "to express intense and often negative emotions" 58 (emphasis added).

To be sure, there are serial works of a gentle lyricism-Dallapiccola's Quaderno musicale di Annalibera, for example-and serial works of a playful nature-certain movements of Schoenberg's op. 25 Piano Suite, perhaps, but the fact still remains that the vast majority of listeners find the absence of familiar signposts and cadential breathing spaces unsettling. In short, a century after

54 Hermann Bahr, Expressionism, trans. R. T. Gribble (London: Henderson, 1925), 84.

55 Quoted in Robert S. Wistrich, Laboratory for World Destruction: Germans and Jews in Central Europe (Lincoln: University of Nebraska Press, 2007), 11.

56 Thomas Harrison, 1910: The Emancipation of Dissonance (Berkeley: University of California Press, 1996), 47.

57 Theodor W. Adorno, Philosophy of Modern Music, trans. Anne G. Mitchell and Wesley V. Blomster (New York: Seabury, 1973), 142.

${ }^{58}$ Joseph N. Straus, "A Revisionist History of Twelve-Tone Serialism in American Music," Journal of the Society for American Music 2, no. 3 (August 2008): 377. 
Schoenberg's plunge into atonal waters, more than three-quarters of a century after his first serial works, and more than a half century after his death, the jury, its seems obvious, is no longer out. It may be, of course, that most people, seduced by the anesthetizing vacuity of mass culture, do not want to confront the harsher truths that much contemporary art has explored and exposed.

The resurgence of interest in Rochberg's music gives credence to Alexander Ringer's strong endorsement and his declaration that the composer had already achieved (by 1965 in Music for the Magic Theater) "that complete independence from the past which is given only to those who have so fully absorbed it that it has ceased to burden the present, showing instead the way to the future." 59 Although Ringer's claim-from our much later vantage point-now appears a bit inflated and premature, only Rochberg's harshest critics would deny that the composer did eventually shed the burden of the past, and few would deny that he deserves a special place in the annals of American music as one who did indeed show a way forward. This much seems self-evident.

Whatever the fate of Rochberg's music might be, his passionate defence of his aesthetic position over more than four decades was a welcome challenge to entrenched academic orthodoxy that gave a new generation the permission to roam freely through the labyrinth that connects the present to the past, affording us from time to time a glimpse of who we are, individually and collectively. Back in the heyday of "academic" modernism, Rochberg saw that if high-culture music were to avoid a kind of cultural suicide, it was necessary to arrive at a renewed understanding of our relation to tradition, continuity, and memory:

Continuity and tradition are the connecting links essential between generations that bind them together through the passage of time. Memory is the human root of tradition and its continuity, the mysterious neuro-biological capacity which makes the past a living force welded to the present. Memory is, in fact, the value-endowing power in all vital human endeavor. If memory fades, we lose the past, its meaning and anchoring wisdom."6o Although there is no evidence that Rochberg knew the works of Giovanni Boine, his remarks concerning continuity and tradition, memory and meaning, bring to mind one of the Italian writer's aphorisms from his Frammenti of 1915: "For my life is not constructed on the basis of a project, piece by piece, like buildings made of stone, and I run toward no goal like a horse to the finish. I have no future for I have no past. Lacking memory, I even lack hope. ${ }^{61}$

59 Alexander Ringer, "The Music of George Rochberg," Musical Quarterly 42, no. 4 (October 1966): 426.

60 Quoted in Guy Freedman, "Metamorphosis of a 2oth Century Composer," Music Journal 34, no. 3 (March 1976): 38.

61 Quoted in Harrison, 1910, 75. 


\begin{abstract}
An exploration of George Rochberg's much-publicized rejection of musical modernism-in particular serialism - in the early 196os. The paper will explore Rochberg's conception of musical time and space, duration in music and its relationship to the roles of memory, identity, intuition, and perception in the shaping of human experience. It will explain his notion of the "metaphysical gap between human consciousness and cosmos," which he derived in part from Wittgenstein's proposition that ethical and aesthetic judgments lie outside the property of language. In Rochberg's view, serialism fails to provide an organic three-dimensional model of duration as experienced through the human perception of time: past (memory) and future (anticipation) become conflated into a continuous present, and the crucial balance between information and redundancy has malfunctioned.
\end{abstract}

\title{
RÉSUMÉ
}

Une exploration du rejet bien connu, chez George Rochberg, du modernisme musical - plus particulièrement du sérialisme - au début des années 1960. Cet article examine la conception que Rochberg se faisait de l'espace et du temps musical, de la durée en musique et de ses rapports avec la mémoire, l'identité, l'intuition, ainsi que la perception dans le développement de l'expérience humaine. Il explique la notion d'« écart métaphysique entre la conscience humaine et le cosmos » que Rochberg fait en partie remonter à la proposition de Wittgenstein selon laquelle le jugement éthique et esthétique résiderait en dehors des propriétés du langage. Selon Rochberg, le sérialisme ne parvient pas à fournir un modèle organique tridimensionnel de la durée qui correspondrait à celui qui provient de la perception humaine du temps : passé (mémoire) et futur (prévision) fusionnent en un présent continu, et l'équilibre décisif entre information et redondance se révèle défaillant. 